\title{
China-Zambia political and economic relations in historical context
}

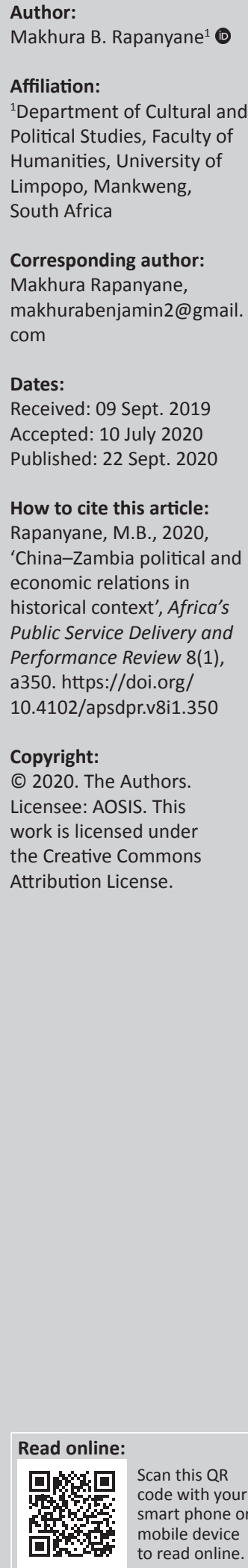

Background: The Scholarship of China-Zambia relations is gaining immense attention due to the emerging mainstream media reports that Zambia is set to loose its State Owned Power Company (ZESCO), National Broadcasting Corporation and Kenneth Kaunda International Airport to China.

Aim: To determine the influence of Zambia's political and economic environment in China's engagement with the African country.

Setting: Based on historical sensibility, this research article uses Zambia's political and economic fertile grounds to revisit what drives the Chinese engagement in Zambia within a historical context.

Methods: This research article employed qualitative research approach in the form of primary and secondary data collection. Complemented by a combination of Afrocentric research methodologies (reinforcer of qualitative method) and thematic content analytic tools.

Results: It has been established that China has managed to gain nefarious fangs into most of the Zambian mineral resources due to the African country's strong political environment and fertile economic conditions.

Conclusion: China's Africa engagement is driven by the local conditions which allows it to do business without any worry, or fear or instability. Thus, Zambia can be seen as one of the best test case points, through an Afrocentric point of view.

Keywords: China; Zambia; economic environment; political environment; foreign policy.

\section{Introduction}

Looking at the studies conducted by Transformation Index BTI (2018), \#AfricanCan (2019) and African Economic Outlook (2019), it was discovered that the fundamental objective behind the undertaking of this research was not addressed. As such, this article leans on thematic content conversations and interdisciplinary discourse analysis and discusses China's engagement with Zambia, with a special focus on how Zambia's political and economic environments influenced and continue to influence China's engagement with Zambia in policy context and other collaborations between 2010 and 2018. In this article, the term 'engagement' is used interchangeably with 'foreign policy' to symbolise the Asian tiger (China)'s international relations with Zambia. The author embraces the view that both China and Zambia are independent states with individual foreign policies outlining how they wish to interact with other countries in the international arena. The problem identified in reviewing other studies is related to the role played by both political and economic environments in China's engagement with Zambia. In this context, it is important to note that China seems to be extensively involved in Zambia, which raises the question of what really influences China's engagement with Zambia. It is noteworthy that this article discusses both Zambia's political and economic environments in order to draw a clear understanding of what could be motivating China to engage extensively with Zambia in the Southern Africa.

\section{Aim and objectives}

This article sought to explain how Zambia's political and economic environments work to influence China's extensive international involvement in Zambia. The main objectives of this article are to explain China's engagement with Zambia within a historical context and therefore to trace Zambia's political and economic environments and situate them in the context of China's engagement with the African country. This discussion is followed by a critical contextualisation 
of to what extent the political and economic conditions of the African country play a role in China's extensive involvement in Zambia.

\section{Research methodology}

Methodologically, this article has relied on a qualitative research approach that included collecting secondary data and adding structured interviews with six postgraduate Master's and Honours students in the field of international politics, foreign policy analysis and international political economy, respectively. The secondary data consisted of a collection of relevant books, journal articles, periodical articles and official and policy documents. Data were analysed using thematic content analysis (TCA), which is very famous in qualitative studies.

\section{China-Zambia relations within a historical context}

The history of Sino-Zambian relations goes back to the period proceeding Zambia's political independence from the United Kingdom (UK) in October 1964. Before its independence, Zambia was still called Northern Rhodesia. China is often referred to as the country that was the leading figure to support Zambia's political emancipation struggles throughout the colonial times by the form of financial and material support (Sethole 2019). Qiang (2007) argued that China's engagement with Zambia is subdivided into three phases: the first phase is from 1949 to 1979 , the second phase is from 1979 to 1999 and the last phase is from 1999 to the present period. The first phase focused on obtaining political freedom from colonialists and also promoting diplomatic ties with China. After Zambia gained its political freedom in 1964, China started to aid Zambia with infrastructural buildout (Mwanawina 2008). After this major victory, the Zambian government started with plans to erect transportation links to help the country's economic growth and endorsement of political freedoms in the Southern African Development Community (SADC) region from colonialists. By then Zambia was part, economically dependent on the sea towards the south, which was by the time under the total control of the apartheid regime of South Africa (Mwanawina 2008).

To achieve the partly economic dependence on the sea, Zambia sought support from Tanzania to make plans of seeking conditional aid from Western countries and the Soviet Union for building their own transportation linkage, which unfortunately did not work out (Ministry of Foreign Affairs, the People's Republic of China 2000). Their turneddown request motivated Julius Nyerere (former president of Tanzania) to rather seek economic assistance from China in 1965 to get help in order to erect Tanzania Zambia Railway Authority (TAZARA Rail line project) ${ }^{1}$ from Tanzania to Zambia (Ministry of Foreign Affairs, the People's Republic of China 2000). China first welcomed this request with one hand as it awaited the Zambian government. Kenneth Kaunda

1.The TAZARA Railway and the Uhuru Railway is a railway project in East Africa interlinking the town of Kapiri Mposhi in Zambia's central province with the port of Dar linking the town of Kapiri Mposhi in Zambia's central province with the port of Dar
es Salaam in east Tanzania. The single-track railway is under the Tanzania-Zambia Railway Authority and it is $1860 \mathrm{~km}$ long. (former president of Zambia) made a special visit to China in 1967 to second the request of Nyerere. After this request was finalised by the three involved parties, China started with the construction plans with effect after all states had signed 'Agreement of the Government of the People's Republic of China, the Government of the United Republic of Tanzania and the Government of the Republic of Zambia on the Construction of the Tanzania-Zambia Railway' in Beijing (Ministry of Foreign Affairs, the People's Republic of China 2000). The TAZARA project started in 1970 and was completed in 1976. As of today, this project is the largest of the Chinese projects in Africa. This phase can also be described as the political and infrastructural development phase. This should be understood in the context that China intended to assist African countries with both political support and infrastructural development. The second phase was met with significant changes as African countries were entering into a period of political and economic modifications. A case in point would be that of Zambia when it encountered huge economic decline because of huge loans, which it acquired from the International Monetary Fund (IMF) and the low prices of coppers in London Metal Exchange (Qiang 2007).

It can be argued that the second phase also contextualised a period of uncertainties, particularly as it relates to Zambia having managed to establish multi-party democracy. As this was happening, on the other side, China was facing the social and economic ills brought about by the 'Great Proletarian Cultural Revolution' that was led by the capitalist reform of policies of Deng Xiaoping (former Chinese leader), which gained significance (Mwanawina 2008:1). Equally important was China's policy of 'going out' that hit African countries with a surprise when it was actualised in the early 1990s. The time and context of this policy moved China away from political and infrastructural concerns in Zambia to economic development by undertaking opportunities, which were to ensure that the Asian tiger grabs global economic opportunities (Mubita 2013). It is equally noteworthy to highlight that even if this was the case, China's engagement with Zambia during the early 1990s was signified by very little economic collaboration, which was diplomatically magnificent (Mubita 2013). However, the period of the second phase of China-Zambia relations, things turned around and economic win-win situation gained momentum. The contemporary third phase dates back to 1999 and is characterised by the intensification of cultivating maintainable economic development by both China and Zambia (Mubita 2013). Top priorities of Sino-Zambia relations in this period can be seen with their attempts to reduce the escalating employment rate in Zambia by huge Chinese investments and also the furtherance of peace in the SADC region. This phase is also led by the Forum on China-Africa Cooperation (FOCAC) as the architect of China-Africa relations. Thus, to increase its economic capacity as an African country in order to be a better partner, Zambia also became a member of both Common Market for East and Southern Africa (COMESA) and SADC, respectively (Mubita 2013:5). China managed to invest heavily in Zambia 
and now records at least $10 \%$ yearly economic growth and had also managed to grow into a significant global economic hub even though the world economy is still controlled by Western countries (Lubinda \& Jian 2018). After 2000, FOCAC as an engine of economic growth that drove the Sino-Zambian relations managed to introduce the following principles or pillars, which represent both countries' collaborations: political equality, complementary trust, economic win-win partnership and cultural exchange (Dynamic 2015; Lubinda \& Jian 2018; Mwanawina 2008). Thus, the periodic revision of FOCAC has ensured that the Asian tiger expands its investment in Africa and Zambia, respectively, with no deviation (Mwanawina 2008). The pillars of China's Zambia policy in this study are also signified to show what really interconnects both the countries. The motive is to show what pillars China's foreign policy towards the African country.

\section{China's Zambia policy: Contemporary pillars and/or integrated principles}

China's foreign policy towards Zambia with a central focus on the context of pillars and/or integrated principles in this article shows that the 2006 China's Africa Policy White Paper highlighted mutual support, correlative welfare, companionship and fairness, trustworthiness, trade-off, continual habitual influence and interactive subsistence as the pillars of China's Africa policy (Mwanawina 2008). Dynamic (2015) is of the same view that China had also started to prioritise or champion a mutual support and integrity, strategic collaboration, economic win-win partnership and interactive benefit as the signs of China's Zambia policy.

Strauss (2009) and Barton (2014:3) observed that Chinese investments in Zambia date back to the 'Open door Policy' of 1978. The Asian tiger likes to promote win-win partnership with emerging economies (1982) and Africa policy White Paper $^{2}$ (1996) and also the 2006 China-Africa Policy White Paper. The White Paper illustrated that China and Africa ought to 'treat each other as equals, develop sincere friendship, strengthen solidarity and cooperation and seek common development' (Barton 2014:3). Equally noteworthy in the discussion of China-Zambia relations is the Belt and Road Initiative (BRI) of China, which now is in the forefront of China's engagement with African countries (Balding 2017). This initiative is seen as the largest infrastructural and investment initiative in the history of mankind (Sethole 2019). This initiative therefore serves as China's global policy plan to interact with Africa, Europe and Asia's infrastructural gap and expand these continents' economic development. African countries such as Zambia continue to benefit from BRI even to date (Phiri 2018).

This initiative as the contemporary policy blueprint that guides Xi Jinping's (Chinese president) relationship with Africa embraces the construction of Africa's railways,

2.This is an authoritative guide or report that advises readers precisely about a compounded issue and advocates the issuing body's philosophy on the matter. It is designated to assist academics and readers in comprehending an issue, solve a problem or make a resolution. telecommunications, roads, sea and air travels as well as maritime to unfasten road travels (Mwamba 2018). Sethole (2019) and Ngoepe (2019) argued that BRI has ensured that African countries, such as Zambia, came to realise their own infrastructural development ambitions. Economically, it remained informative that China's 1996 and 2006 policy papers on Africa, respectively, signified huge investment in African countries, such as Zambia, and also highlighted simple readiness to engage in free trade deals with African countries (Wo-lap 2016). In this context, African market access became important under the significant instincts of resource collaboration, which highlights a conclusive remark that China only wants access to the huge abundance of Africa's and Zambia's natural resources (Lubinda \& Jian 2018). Drawing from China's historical engagement with Zambia, this is deemed necessary to redirect the focus to the central objective of this article. This manifested in the discussion of Zambia's political and economic environment.

\section{Zambia's political and economic environments}

\section{Political environment}

In advancing the argument of this article, it is important to try and show how Zambia is doing politically. This sentiment should be understood within the context of a critical analysis of Zambia's political stability and instability. As such, in the time context of this article, Zambia's 2011 and 2016 parliamentary and presidential democratic elections were considered to be free and fair (Electoral Commission of Zambia 2016; Zambia 2011). In 2011, Michael Sata stepped in as president together with his political party, Patriotic Front (PF) (Ngoepe 2019). After his victory, Sata started to execute some of the promises he had made before elections to his people, especially in the areas of labour force in the formal sector and increased common social spending. His government was doing its work even though there were turbulent leadership practices and the absence of sufficient democratic consultations between his government and the civil society organisations (Transformation Index BTI 2018). In fact, those who did not have a say in the new government of Sata became critical of his government, for example, The Post and national newspapers. Even though this was the case, Sata's government was very much stable and politically legitimate because of the democratic outcome. In other words, Sata's administration could have motivated Chinese involvement in Zambia especially when it came to the dispatchment of Chinese mining businesses into Zambia's secondary sectors (e.g. mining) (Lubinda \& Jian 2018).

The death of Sata on October 2014 warranted a need for a presidential by-election run as he died in office. There were a number of incidents depicting a short period of political instability as the news of Sata's ill health spread in the internal factions of Patriotic Front raising a struggle for succession (Transformation Index BTI 2018). After Sata's death, the PF had already united behind the name of Edgar Lungu as the rightful candidate to take over the power helms and unite PF. His main opponent was Hakainde Hichilema of the United Party for National Development (UPND). 
Even though Hichilema's party rose from a $18.17 \%$ support in the country to $46.67 \%$ support, Lungu managed to score 27000 votes, which made him to retain power with his PF party (Transformation Index BTI 2018). These elections were announced free and fair by the SADC Electoral Observation Mission. The mission announced 'peaceful, free, transparent, credible, free and fair, thus reflecting the will of the people of Zambia' (Electoral-Commission-of-Zambia, 2016:1). Election contraventions were only spotted in occasions of voting registrations for those in the local areas who had moved with only less violence instances of party rivalry reported. His rise to power with at least 27000 votes was considered a waferthin margin win, and set up debatable election outcomes in 2016 (Ngoepe 2019).

As of today, Zambia is seen as a stable African country with least, but prosperous, democratic elections held on a 5-year basis (Maphoto 2019). Zambia's incoming elections will be in 2021. The current incumbent (Edgar Chagwa Lungu) of the PF was officially inaugurated in 2016 in a closely monitored presidential contestation with his opponent, Hichilema of the UPND (\#AfricanCan 2019). According to the 2018 Global Innovation Index (GII), Zambia is economically and politically stable, meaning that it is amongst the African countries that can be regarded as peaceful (Lusakatimes 2018). The GII shows that Zambia stands at 54 out of 126 countries on the grading of global countries on economic and political stability in 2018 (Lusakatimes 2018). Zambia as a middle-income African country has been classified as one of the countries with a good record of adhering to international law and had been rated as number 80 out of the 126 countries rated by the GII. This report was read and put to the public at the event that was organised at Roosevelt Island (Cornell University Campus) by World Intellectual Property Organization (WIPO) in New York (Lusakatimes 2018). The GII report extended gratitude by highlighting that Zambia had shown signs of robustness of the business environment and also in settling insolvency. There is no strict governmental restrictions on international investment, making business environment more conducive without problems of liquidations (Lusakatimes 2018).

\section{Economic environment}

Zambia illustrates freedom of trade, currency convertibility, liberalisation of foreign trade in principle, free usage of profits and also the freedom of pricing. The country's capital markets together with the banking system are compared, oriented and differentiated with international grades in principle (Transformation Index BTI 2018). The author argues that Zambia has signs of the most liberal banking rules in the SADC region and the country's bank sector therefore works well. This means that there is a utilitarian banking supervision combined with less capital conditionalities. Capital merchandises are easily accessible to both foreign and domestic capital. Although in rural areas property rights are not well defined, they are well defined in urban areas. A case in point would be that of the Barotseland's agricultural land which remains under the authority of traditional leadership.
Therefore, it is conclusive to say that in rural areas, property rights are not easily defined and enforced as the difficulty is caused by the land controlled by traditional leaders (Transformation Index BTI 2018).

In economy, gross domestic product (GDP) had declined from $4.1 \%$ in 2017 to $4.0 \%$ in 2018 . Agricultural production lessened by $35 \%$ because of the shortage of rain experienced in 2018 (African Economic Outlook 2019). With regard to mining, copper output had increased with at least $4.5 \%$ in 2018 as compared to the last 10 years. Infrastructural construction has assisted the Zambian economy as there was a huge investment in public infrastructure, towing cement production and commercial buildings, which grew with $10 \%$ as compared to the last decade (African Economic Outlook 2019). Zambia recorded a favourable economic growth between 2004 and 2014, with a yearly GDP growth rate of 6.7\%. However, between 2015 and 2017, it decreased slightly with the reasons attributed to Kwacha's ${ }^{3}$ depreciation, reduced power generation and decreasing copper prices (Index Mundi 2018). Thus, the African country's deficiency in economic diversification and huge dependence on copper as the sole principal export lead its vulnerability to the variations of the world commodities markets (Moody's Analytics 2019; Zambia Economy 2019). In 2017, Zambia's GDP grew as the prices of minerals grew. Despite this strong economic development and its status as a developing country, Zambia is still a victim of high birth rate, high unemployment rate and HIV and AIDS, market-manipulating energy and agricultural policy blueprints and high level of governmental debt. That is why the country 'raised $\$ 7$ billion from international investors by issuing separate sovereign bonds in 2012, 2014, and 2015' (Moody's Analytics 2019; Zambia Economy 2019).

\section{Contextualising the role of Zambia's political and economic conditions in China's continued engagement with the African country}

Firstly, Zambia is continuously engaging in different measures to upgrade the country's business environment. As such, it established the Private Sector Reform Development Programme (PSRDP) to recurve on further efficient business licencing methods and improve alternative supervisory procedures aligned with business undertakings (UNCTAD 2011). Besides this, the formation of Zambia Development Authority (ZDA) in 2007 consolidated and vindicated investment advancement and furtherance. Under the guidance of ZDA, a liberal impetus project was made accessible and the aftercare servicing was furnished. The formation of multifacility economic zones furnished international investors such as Chinese multinational corporations (MNCs) with more well-equipped and secured economic environment for operation. Eventually, Zambia's reforms also took place in the arena of custom clearings, automated registration, visa and permits processing and registration of land in order to be accommodative. The country's labour laws were lessened to curb extensive governmental intervention (UNCTAD 2011).

3.The kwacha is the currency of Zambia. It is subdivided into 100 ngwee. 
The above discussion shows that Zambia is doing very well economically and has the environment that is easy for doing business. This implies that China is into some extent attracted by Zambia's stable and open economic environment.

Apart from being a member of SADC Free Trade Area (SADC-FTA), Zambia also has its market reaching at least 170 million people in a SADC market of up to US $\$ 360$ billion. In addition, Zambia is also a member of the COMESA, which is the biggest regional association in Africa with 400 million people comprising of 19 member countries (Ngoepe 2019; UNCTAD 2011). The regional infrastructural projects, such as the North-South Corridor Project, link Zambia's copper belt to the port of Dar el Salaam, and even across southern ports of South Africa, locating Zambia as a land-linked conveyance hub to its bordering countries. This rail and road travel, if improved and nourished, can help the transportation of movements in the region to be more fluid (Maphoto 2019). This discussion is an addition to Zambia's outside economic relations, which shows that, indeed, the African country is committed to open its markets to international investment.

Zambia's mineral resource complex, which is worth an estimated 2 billion tons founded in the copper belt region, can be able to grow and further expand the country's mining industry. Despite copper that is in high demand from Chinese investors, Zambia also possesses diamonds, amethyst, emeralds (precious stones), gold and aquamarine. Zambia has about $58 \%$ of arable land and also an estimated $750000 \mathrm{~km}^{2}$ of landmass. In 2011, Zambia started processes of delivering accessibility to both international and local investors to brand new farming blocks too for agrobusiness and cultivation purposes (UNCTAD 2011). Zambia also promotes both floricultural and horticultural crops in the export markets of South Africa and Europe (Ngoepe 2019). The preceding discussion means that Zambia has enough chances of investors engaging in agro-processing and advance investment and value chain using joint business undertakings. Zambia's potential in tourism is heavily indebted to its own abundance of natural resource complex, the lion's share of which is unexploited and pristine and caters a divergent and extensive scope of interests, encompassing national heritage, adventure activities, diverse culture, varied sceneries, wildlife and wilderness (Maphoto 2019). Apart from the Victoria Falls (a world famous United Nations Educational, Scientific and Cultural Organization [UNESCO] heritage site), Zambia has up to 34 game management areas and 19 national parks enveloping at least 22.4 million hectares of land (Sethole 2019).

Zambia's foreign direct investment (FDI) matters are determined by the 2006 ZDA Act, which became effective from 2007. Upon its execution and replacement of Zambian Investment Centre (ZIC), the Act introduced liberal investment climate in order to obtain investment and employment creation. This Act also ensured that stricter rules are abided especially when it comes to foreigners and investors obtaining resident permit (Kragelund 2009).
This Act does not specify conditionalities attached to the local content, equity, technology transfer, subcontractors and employment for foreign investors or even specify if Chinese and other investors are required to commit to domestic participation or perhaps matters of Corporate Social Responsibility (CSR). This Act permits foreign investors (e.g. Chinese investors) to transport any capital portions freely and send their families the profits, interests, fees, royalties and dividends. To be precise, this Act allows foreign nationals (e.g. Chinese investors) to send wages earned in Zambia back to China (Kragelund 2009). The sentiments expressed above embody the view that Chinese business nationals in Zambia enjoyed and continue to enjoy Zambia's friendly political and economic environments and the benefits behind them.

Another significant aspect of this discussion is trade fair that is considered an annual occurrence, which is financed by both the Henan Provincial leadership and the Bank of China. This event calls for international and domestic investors to establish business-to-business linkages and explore investment opportunities in Zambia (Chimanse 2017). During the 2017 session of the trade fair, Xu Jianhua, the vice president of Bank of China's Henan Province Branch, articulated that Chinese business firms seek to do their investment and business ties with African countries such as Zambia, which are seen as best destinations because of their steady political economies and primary resources (Chimanse 2017). The Zambia Development Authority also presented on the investment opportunities offered by Zambia, which are significant to the economy of Zambia. The ZDA's presentation on the investment opportunities deliberated on the kind of investment climate Zambia possess, incentive structure and the legal framework, which ensure the safety of all investment measures.

\section{Discussion of the findings}

In this article, the author discovered that China's engagement with Zambia is influenced by the following factors: Zambia's political and economic stability as reflected by the successful democratic elections held every 5 years. The foregoing should be understood in the context that even GII rated Zambia as both economically and politically stable. Zambia also adheres to the international law and possesses strong governmental institutions under the classifications of political environment. Under the category of economic environment, Zambia had simultaneously shown signs of freedom of currency conversion, pricing, profits transportation and free trade. To be precise, Zambia has fundamental elements of liberal trade, which conform to the international laws governing World Trade Organization (WTO), making it easy for Chinese investors to trust Zambia as one of the suitable and conducive environments in Africa for investment.

\section{Conclusion and recommendations}

The principal aim of this article was to determine the influence of Zambia's political and economic environment in China's engagement with the African country. The empirical 
investigation of this article shows that China's historical engagement with Zambia dates back to the last six decades and they both had well-nourished economic and political relations. This is supported by the findings of this article, showing that during the colonial times, and even after colonialism, China supported Zambia economically, for example, through the TAZARA project. In addition, this article also shows that China's engagement with Zambia is pillared by China's Africa policy papers of 1990 and 2006, which elaborate the integrated principles of China's foreign policy towards Africa and Zambia. To add, since 2000, FOCAC has been the engine that drove and became the pillar of China-Africa relations. Therefore, even BRI can be better explained in the context of FOCAC for a better understanding of how China seeks to engage with Africa. For the purpose of illustrating the central focus of this article, it is informative that Zambia's political environment had been so fertile that there are no electoral violations as it has been seen by both international and SADC electoral observation missions to have had free and fair elections in the past decade (2011, 2016). The exploration of this article also shows that WIPO has admitted that property rights are protected in Zambia. Another significant aspect of this discussion is the country's economic liberalisation, which ensures that there is free trade and freedom of transporting profits back to China. What is most important is that the country is rich in copper, which had become a need for Chinese economy. This is what motivates China's flourishing engagement with Zambia. As such, a fundamental recommendation for Zambia in this instance is to prolong its political and economic stabilities to continue attracting more and more Chinese FDI for employment and infrastructural development opportunities.

\section{Acknowledgements}

The author is indebted to Ms. Florence Ramasela Sethole for her peer review services and the late Ms. Bopape Lisbeth for technical services (may her soul rest in peace).

\section{Competing interests}

The author declares that no competing interest exists.

\section{Author's contributions}

I am the sole author of this article. I conceptualised and led the operationalisation of this research article, performed editing of the entire article and solely attended to all queries and corrections in various post-review stages towards the production of this article.

\section{Ethical consideration}

This article followed all ethical standards of carrying out a research in terms of data collection.

\section{Funding information}

This research received no specific grant from any funding agency in the public, commercial or not-for-profit sectors.

\section{Data availability statement}

Data sharing is not applicable to this article as no new data were created or analysed in this study.

\section{Disclaimer}

The views and opinions expressed in this article are those of the author and do not necessarily reflect the official policy or position of any affiliated agency of the author.

\section{References}

\#AfricanCan., 2019, The World Bank in Zambia, viewed 11 June 2019, from https:// www.worldbank.org/en/country/zambia/overview

African Economic Outlook, 2019, Zambia economic outlook, viewed 06 June 2019, from https://www.afdb.org/en/countries/southern-africa/zambia/zambia-economicoutlook/

Balding, C., 2017, Can China Afford its belt and road? viewed 10 April 2019, from https://www.bloomberg.com/view/articles/2017-05-17/can-China-afford-itsbelt-androad

Barton, S., 2014, 'Sino-substitution: Chinese foreign direct investment in Zambia', Journal of Chinese Economic and Foreign Trade Studies 7(2), 90-109. https://doi. org/10.1108/JCEFTS-08-2013-0025

Chimanse, M., 2017, ZDA attracts more Chinese investment, May 04, viewed 11 June 2019, from http://www.daily-mail.co.zm/zda-attracts-more-chinese-investment/

Dynamic, B., 2015, What lies ahead for China-Zambia relations, April 10, viewed 11 June 2019, from https://zambiareports.com/2015/04/10/what-lies-ahead-forchina-zambia-relations/

Electoral-Commission-of-Zambia, 2016, General election 2016, viewed 14 June 2019, from https://web.archive.org/web/20160812182511/

Index Mundi, 2018, Zambia vs. Namibia, viewed 08 June 2019, from https://www. indexmundi.com/zambia/economy profile.html

Kragelund, P., 2009, 'Knocking on a wide-open door: Chinese investments in Africa', Review of African Political Economy 36(122), 479-497, viewed 11 June 2019, from https://www.jstor.org/stable/27756307

Lubinda, C. \& Jian, C., 2018, 'China-Zambian economic relations: Current developments, challenges and future prospects for regional integrations', International Journal of Economics VI(1), 206-223.

Lusakatimes, 2018, Zambia ranked politically and economically stable by the Globa Innovation Index, July 17, viewed 11 June 2019, from https://www.lusakatimes. com/2018/07/17/zambia-ranked-politically-and-economically-stable-by-theglobal-innovation-index/

Ministry of Foreign Affairs, the People's Republic of China, 2000, China's assistance in the construction of the Tanzania-Zambia Railway, November 17, viewed 11 June 2019, from https://www.fmprc.gov.cn/mfa_eng/ziliao_665539/3602_665543/ 3604_665547/t18009.shtml

Moody's Analytics, 2019, Zambia- economic indicators, viewed 11 June 2019, from https://www.economy.com/zambia/indicators

Mwamba, E., 2018, Zambia-China, An intricate relationship, viewed 12 April 2019, from https://www.lusakatimes.com > Columns.

Mwanawina, I., 2008, China-Africa economic relations: The case of Zambia, viewed 11 June 2019, from https://aercafrica.org/wp-content/uploads/2018/06/1Zambia. pdf

Personal interview with CC Ngoepe, 2019, 'Role of political and economic considerations in the influence of China's Zambia policy', Student Reseacher (International Relations), University of Limpopo, Mankweng, (06 2).

Personal interview with TE Maphoto, 2019, 'Role of political and economic considerations in the influence of China's Zambia policy', Student researcher (International Relations), Mankweng, (06 05).

Personal interview with FR Sethole, 2019, 'Role of Political and Economic considerations in the influence of China's Zambia policy', Student researcher (International Relations), University of Limpopo, Mankweng, (06 05).

Phiri, K., 2018, Major policies that have shaped China, viewed 10 June 2019, from www.daily-mail.co.zm/major-policies-that-have-shaped-china

Qiang, Z., 2007, China-Africa relations since introduction of FOCAC, China Institute of Contemporary International Relations, Beijing.

Strauss, C., 2009, The past in the present: Historical and rhetorical lineages in China's relations with Africa in Strauss, J.C., Saavedra, and M. (Eds), China and Africa: Emerging patterns in globalization and development, Cambridge University Press, Cambridge.

Transformation Index BTI, 2018, BTI 2018 / Zambia country report, viewed 11 June 2019, from https://www.bti-project.org/en/reports/country-reports/detail/itc/ZMB/

UNCTAD, 2011, An investment guide to Zambia: Opportunities and conditions, viewed 11 June 2019, from https://unctad.org/en/Docs/diaepcb201008_en.pdf

Wo-lap, W., 2016, Getting lost in 'One Belt, One Road', viewed 10 April 2019, from http://www.ejinsight.com/20160412-getting-lost-one-belt-one-road/

Zambia, 2011, Presidential elections results, viewed 19 October 2019, from http:// www.zambian.com/html/zambia-elections-results.html

Zambia Economy, 2019, Economy- overview, viewed 11 June 2019, from https:// theodora.com/wfbcurrent/zambia/zambia_economy.html 